\title{
The British Columbia College of Teachers: An Obituary
}

\section{Alastair Glegg}

\section{ABSTRACT}

The British Columbia College of Teachers operated from 1987 to 2011, a period extraordinary for the amount of conflict generated. The British Columbia Teachers' Federation appeared to view the College not as a professional association, but as an extension of the union. It came into conflict with the universities over teacher training, and appeared reluctant to discipline members, or to listen to complaints against teachers. Following a highly critical report the College was replaced by the B.C. Teachers' Council, a body much more tightly controlled by the Ministry of Education.

RÉSUMÉ

Le British Columbia College of Teachers (l'association professionnelle des enseignants de la Colombie Britannique) a existé de 1987 à 2011. Cependant, la Fédération des professeurs de cette province percevait ce regroupement non pas comme une association professionnelle mais plutôt comme un syndicat. Ce fut une période agitée due au nombre de conflits générés par cet organisme. Ainsi, le "College " est entré en conflit avec les universités au sujet de la formation des maîtres, il n'imposait aucune discipline à ses membres et ne tenait pas compte des plaintes formulées contre eux. À la suite d'un rapport très critique à son endroit, le "College " fut remplacé par le B.C. Teachers' Council, organisme sous le contrôle rigoureux du ministère de l'Éducation.

\author{
Solomon Grundy, \\ Born on Monday, \\ Christened on Tuesday, \\ Married on Wednesday, \\ Took ill on Thursday, \\ Worse on Friday, \\ Died on Saturday, \\ Buried on Sunday, \\ That is the end of Solomon Grundy! \\ (Old English Nursery Rhyme)
}




\section{Conception}

Traditional professions such as law and medicine typically determine their own entrance qualifications, and have the legal right and responsibility to discipline their members. This is not generally the case with school teachers: in most cases some branch of government, such as a Department of Education, sets the required standards, issues certificates, and handles matters of conduct and competence. The Canadian province of British Columbia was one of the first jurisdictions to grant teachers many of the privileges and responsibilities enjoyed by doctors, lawyers, architects, and other professional groups. It might be expected that such a decision would be welcomed by teachers considering that self-governance is one of the standard attributes of 'professionalism', ${ }^{1}$ but the brief existence of the British Columbia College of Teachers was pockmarked by political wrangling, power struggles, and protracted lawsuits. This paper examines the College's 25 year lifespan, explores and attempts to explain its troubled adolescence, and suggests some reasons for its early demise.

\section{Born on Monday}

In 1987, the British Columbia College of Teachers was created by the provincial government with the passage of the Teaching Profession Actwhich also permitted teachers to unionize. ${ }^{2}$ The birth of the College was surrounded with controversy, coming as it did at a time of intense confrontation between the government and public sector labour unions, including the British Columbia Teachers' Federation (BCTF). ${ }^{3}$ The BCTF had been pressing for the legislated authority "to govern the rights and responsibilities of the teaching profession," but was opposed to the granting of these powers to another organization. ${ }^{4}$ The 1988 Royal Commission on Education noted this, observing that "the language of the Teaching Profession Actsuggests that one of the intents of the government's enactment of . . . the Teaching Profession Act was a desire to separate the professional and union functions of teachers." 5 The College of Teachers was modelled along the lines of the General Teaching Council for Scotland, and was intended to perform functions carried out in other similar professions by such bodies as the College of Registered Nurses of British Columbia or the College of Physicians and Surgeons. ${ }^{6}$ It assumed some responsibilities previously held by the Ministry of Education, most notably the issuing of teaching certificates and control over disciplinary matters. All certified teachers in British Columbia automatically became members of the new College, and this included not just public school teachers, the members of the BCTF, but all others holding teaching certificates: school district staff (including superintendents, directors of instruction, principals, and vice-principals), many independent school teachers, and numerous former teachers, such as university faculty members and Ministry of Education officials. The College was to be governed by a council of 20 persons, five appointed by the Minister of Education, and 15 elected by members of the College. The legislation set out three statutory committees: a Qualifications Committee which would oversee the admission, certification, and 
reinstatement of members; a Disciplinary Committee which would deal with matters of teacher competence and conduct; and a Professional Development Committee which would "carry out, cooperate in or facilitate programs of professional development ... [and] cooperate with teacher training institutions in the design and evaluation of teacher training programs."

\section{The Main Protagonists}

\begin{tabular}{|l|l|}
\hline BCTF & $\begin{array}{l}\text { British Columbia Teachers' Federation, also referred to as "the Federation" or } \\
\text { "the Teachers' Union" }\end{array}$ \\
\hline BCCT & $\begin{array}{l}\text { British Columbia College of Teachers, also referred to as "the College" or } \\
\text { "the College of Teachers" }\end{array}$ \\
\hline BCPVPA & British Columbia Principals' and Vice-Principals' Association \\
\hline TWU & Trinity Western University \\
\hline UBC & University of British Columbia \\
\hline
\end{tabular}

\section{Christened on Tuesday}

The BCTF's reaction was swift and negative: they had been campaigning for full union status, andoriginally did not want to have school administrators excluded, although the Principals' and Vice-Principals' Association (BCPVPA) had in fact some months earlier set in motion their withdrawal from the Federation, a process which would also require the refund of about four million dollars of their membership fees and contributions to the BCTF's Salary Indemnity Fund. ${ }^{8}$ The Teaching Profession Actdesignated principals and vice-principals as "Administrative Officers," excluding them from membership in local unions, but not from the provincial teachers' association. Nevertheless, the BCTF, in its new role as a formal union, acted quickly to exclude from active membership not only principals and vice-principals, but also any other certified teachers who were officials of the Ministry of Education, school superintendents, or directors of instruction: a clear line was being drawn between 'workers' and 'management,' although it was not until 2003 that the BCTF actually joined the B.C. Federation of Labour, and subsequently the Canadian Labour Congress. ${ }^{10}$ This action also marked the beginning of another trend: the tendency of the BCTF to challenge in the courts government decisions with which they did not agree. It took another seven years and five different court challenges before the BCTF finally agreed to repay the BCPVPA $\$ 3.9$ million. ${ }^{11}$ This dispute, coupled with the creation of the new College of Teachers which would exercise powers that the BCTF had wanted for itself, led to an outbreak of sometimes hyperbolic rhetoric: the President of the Canadian Teachers' Federation described the legislation as "the most monstrous, the most vicious, the most vile attack on the teaching profession in the history of education in our country." 12

It was not an auspicious start: to the government's evident disappointment, all public school district associations voted to become members of a fully-fledged union instead of the rather vague alternative of merely forming non-unionised local associations, and the BCTF itself seemed initially determined to simply ignore the College 
of Teachers, treating it as an unnecessary creation of a hostile government, and one whose duties could very well be carried out by the teachers' union. As will be seen, it is the last point which was to become more and more contentious over the years: the question of whether it is possible or even desirable for one organization to act in the public interest by overseeing the competence and conduct of teachers, and simultaneously to serve as an advocate for those teachers, and their legitimate personal and professional concerns. ${ }^{13}$

\section{Married on Wednesday}

When it became clear that the government was not going to be swayed by strikes and protests, and that the College of Teachers was there to stay, the BCTF changed its approach: the legislation provided for 15 elected members of the Council of the College of Teachers, and the BCTF now had 75 union locals to call upon, thus ensuring them a controlling interest. This unlikely mariage de convénancewas finalized when all 15 candidates endorsed and financially supported by the BCTF were elected to the first Council. At the second election for the Council in 1989 the BCTF withdrew its support from two candidates whom it had endorsed in 1987: one had become a principal, and the other had taken a position with the Ministry of Education, and they were thus disqualified from BCTF membership, a clear indication that this was not to be an equal partnership, but one in which the BCTF wanted to maintain control. ${ }^{14}$ Councillors who were members of the BCTF should "report to the Executive Committee [of the BCTF]," a phrase which clearly indicated the preferred hierarchy. ${ }^{15}$ The small administrative staff of the College were appointed by the Council, with a number of the senior positions being offered to former BCTF officials.

The College soon appointed a committee to conduct a review of existing teacher education programs run by the universities. In July, 1991, this committee submitted a report which included 32 recommendations covering almost every aspect of teacher education from the selection of students suitable for training as teachers, to the desirable qualifications for faculty members, and requirements to address specific social issues. ${ }^{16}$ The Co-ordinator of the External Review Team was highly critical of the direction the University of Victoria's Faculty of Education was taking, something which presumably encouraged the College to take a unilateral rather than a collaborative approach to changes in teacher education:

It has been pulled by the university ethos away from its normal school origins towards graduate programs and research . . . it seems to have mislaid its collective vision, its conceptual purpose of its task as a professional school [sic] . . . we suggest it is indeed time for renewal of the Faculty of Education. ${ }^{17}$

Predictably the province's faculties of education did not look kindly on this threat to their academic and professional autonomy. The statutory responsibility of the College to "cooperate with teacher training institutions" was apparently to be replaced by a more confrontational attitude. 
Following a general election four months later, political power passed to the New Democrats, a party which had always been much more sympathetic to the views of the BCTF. In 1993 the Teaching Profession Act was amended "at the request of the College" to change the title of the Professional Development Committee to the Teacher Education Programs Committee. ${ }^{18}$ The sections dealing with teachers' professional development were completely removed, leaving "the design and evaluation" of teacher education programs as the primary purpose of the committee. ${ }^{19}$ The position of the BCTF on professional development is somewhat ambivalent. While stressing its importance - "one of the primary goals of the BCTF is to promote the continuous career long, professional growth of our members" - it is made clear that this does not involve a compulsory formal, regular program of professional development: "central to all local union provisions is the recognition of professional autonomy of members to plan and pursue their professional growth" - in other words, it is entirely up to the individual teacher. ${ }^{20}$ This change is probably the first formal indication of the shift in priorities of the College of Teachers: most other similar organizations place a strong emphasis on the compulsory continuing professional development of their members. ${ }^{21}$

The original Act also empowered the council of the College to make bylaws "respecting the training and qualification of teachers," and this had been amended in 1990 to add "establishing standards, policies and procedures with respect to the training and qualifications." 22 The power to make bylaws affecting teacher education programs was to become a major point of dispute between the College and the universities, but the first significant confrontation was over the statutory right of the College "to establish, having regard to the public interest, standards for the education, professional responsibility and competence of its members." 23

\section{Took Ill on Thursday}

Over the next few years the College of Teachers began to display rather disturbing signs that it perceived itself as much more than an organization whose primary responsibility was to regulate and monitor the professional qualifications and competence of its members. The statutory requirement to act "in the public interest" became something of a catchphrase, but it begged the question as to who was to determine what exactly this meant, as was clearly shown by the lengthy dispute between the College and Trinity Western University. ${ }^{24}$

Trinity Western (TWU) is a privately funded Christian University, and at that time offered the first four years of a five-year teacher education program, with students transferring to a public university for their final year. Students and faculty members at TWU were expected to adhere to a Bible-based code of Community Standards, including (among many other less controversial provisions) abstinence from homosexual behaviour while attending the University. ${ }^{25}$ In 1995 TWU applied to the College of Teachers for approval of its complete Professional Teacher Education Program, and in 1996 the Program Approval Team of the College recommended accreditation, subject to certain minor conditions. This recommendation 
was endorsed by the College's own Teacher Education Programs Committee, but two days later the College Council met and rejected the application by a vote of 16 to two on the grounds that

It does not fully meet the criteria and because it is contrary to the public interest to approve a teacher education program offered by a private institution, which appears to follow discriminatory practices. ${ }^{26}$

TWU appealed the decision, but the College Council voted to deny the appeal. Although it was not formally stated at the time, there was apparently an assumption that students graduating from a program run wholly by TWU might be biased against homosexuals. TWU challenged the College's decision in the Supreme Court of British Columbia, and two other high-profile organizations lent their support as interveners, the British Columbia Civil Liberties Association, and the Catholic Civil Rights League, both of whichrecognized that the College's decision could potentially have implications extending far beyond the TWU case.

The legal arguments put forward by TWU were based on charges that the College of Teachers had exceeded its jurisdiction when it considered the Community Standards, that the assumption that TWU graduates would be biased was not supported by the facts, and that the decision ignored the Human Rights Act, and failed to consider the guarantees of the Charter of Rights and Freedoms concerning freedom of religion, and equality under the law. ${ }^{27}$ The question of legal authority was clearly the most important, and was the first matter addressed in the court's judgement:

It is obvious that the reference to the public interest does not confer unlimited authority on the BCCT to act, nor does it allow the BCCT to take into account all aspects of public policy which it believes should be promoted. ${ }^{28}$

On these grounds, and because there was no evidence of inappropriate conduct by TWU graduates, the Supreme Court decided that the College was without jurisdiction when it denied TWU's application, and directed it to approve the application, subject to the conditions recommended by its own Teacher Education Programs Committee. $^{29}$

The College of Teachers took the case to the next level, but the Court of Appeal upheld the B. C. Supreme Court's decision, concluding that while the BCCT was entitled to a high degree of deference in setting professional standards, that deference "does not extend to its interpretation of the human rights code and the Canadian Charter of Rights and Freedoms." ${ }^{30}$ The court's decision was not unanimous, however, and Madam Justice Rowles' dissenting opinion was based on her conclusion that the College's decision not to approve TWU's program

Upholds the perception that the public school system will not condone antihomosexual policies [and] should contribute to ensuring that . . . the institutions that train [teachers] maintain high standards of non-discrimination. ${ }^{31}$ 
The split decision of the Provincial Court of Appeal opened the door for a final appeal to the Supreme Court of Canada, and the College decided to take that route: clearly they were convinced of the correctness of their viewpoint, in spite of the opinion of the two provincial courts. Two and a half years later, in May 2001, the Supreme Court handed down its verdict, voting by an eight to one majority to require the College of Teachers to approve Trinity Western's teacher education program. The Supreme Court was very critical of the College's approach, and upheld the lower courts' findings that the College had acted beyond its sphere of authority. While acknowledging that the College could take discriminatory practices into account,

It cannot seriously be argued that the determination of good character, which is an individual matter, is sufficient to expand the jurisdiction of the BCCT to the evaluation of religious belief, freedom of association and the right to equality generally. ${ }^{32}$

The verdict of the Supreme Court was not unexpected, but few observers anticipated such a large majority as previous decisions on matters relating to homosexuality had been markedly sympathetic.However, this case was not primarily about human rights, it was about the role of the British Columbia College of Teachers. The College was found to have exceeded the limits of its authority and was ordered to pay costs to Trinity Western University. Those were substantial, and the College's legal fees and court-ordered costs in this case alone eventually totalled over $\$ 533,000 .^{33}$ The decisions to proceed with the various court cases and appeals were made by the Council of the College. There does not appear to have been any consultation with the 50,000 members whose compulsory annual dues made up the bulk of the College's income, and which were in fact increased by the Council the following year. ${ }^{34}$

\section{Worse on Friday}

While these appeals were working their way through the court system, another dispute had arisen between the College of Teachers and the universities. In March, 2000, the Program Approval Team of the College made recommendations regarding items which would have to be addressed before they would approve a new teacher education program at the University of British Columbia (UBC). These included specific requirements for staffing ratios, representation on committees, and other personnel matters which UBC claimed in court were the "sole prerogative of the University pursuant to the University Act." 35 The other provincial faculties of education supported UBC, forming a group calling itself ABCDE, the Association of British Columbia Deans of Education, which brought at least a glimpse of humour to this otherwise rather grim series of events. The decision of the provincial court was deferred until after the Supreme Court's decision on the TWU case.In his judgement Mr. Justice Bauman noted that the highest court's decision upheld the College's jurisdiction to determine the 'what' of a teacher education program, but not, in his opinion, the 'how'; the duty to cooperate did not imply "a jurisdiction in the College to dictate to 
teacher education institutions ... on matters of program 'design'." He referred the decision not to approve the program back to the College for reconsideration. ${ }^{36}$

The Council of the College was also proposing revisions to its official policies and bylaws, which would impinge on the traditional and statutory rights of the universities to determine the nature of their programs, to say nothing of flouting the concept of academic freedom. For example, these changes would require a university teacher education program to have "a system for assigning tenure, promotion and salary that rewards teaching, supervision of practicum students and research in teacher education," and to "address, through the program, philosophical, ethical, and societal concerns" including gender equity, homophobia and heterosexism, the immigrant experience, poverty, racism, and sexual orientation. ${ }^{37}$ In the rationale for the proposed changes the College's view of its own role was made quite clear:

While the College of Teachers remains committed to the value of ongoing dialogue with faculties of education ... about the nature of teacher education, [it] has the responsibility of protecting the public interest in this area. Difficult and controversial situations should be anticipated and provided for in the bylaws. ${ }^{38}$

It is instructive to note the emphasis on 'the public interest' recurring, in spite of the clear direction of the Supreme Court five years earlier in the TWU case, which had specifically addressed this issue: "Reference to the public interest does not confer unlimited authority on the BCCT to act, nor does it allow the BCCT to take into account all aspects of public policy which it believes should be promoted." ${ }^{39}$ It is also noteworthy that the proposed revisions addressed matters which have been traditional priorities of teachers' trade unions: the appointment, conditions of employment, and remuneration of staff, and a social agenda associated with the political left. ${ }^{40}$ The Teaching Profession Act stated that the bylaws of the College could only be amended by a vote of at least two-thirds of the council present at a meeting, that is 14 out of a total of 20 members if all were present. ${ }^{41}$ The power to change bylaws was thus firmly in the hands of the 15 elected members of the Council, those endorsed and supported by the teachers' union, the BCTF, a fact which was to have increasing significance.

Many of the subsequent changes to the policies and bylaws made specific reference to these 'elected members', ensuring their dominant role on the various committees and sub-committees of the College:

- The quorum for meetings of any committee appointed by the Council . . shall be a majority of the members appointed, provided that a majority of those present are elected Council members;

- A quorum of the Qualifications Committee ... shall be comprised of three elected Council members;

- A sub-committee of the Discipline Committee, to be known as the Preliminary Investigation Committee . . shall be comprised of three elected Council members; 


\section{- A board of examiners. . . shall be chaired by an elected Council member;}

- A Program Approval Team shall consist of three members including a Member of the College of Teachers named in consultation with the British Columbia Teachers' Federation [Emphasis added].

Perhaps the most brazen change was to Policy P1.D.02, innocuously headed 'Rules of Order': "All meetings of the College or the Council of the College shall be conducted according to BCTF Simplified Rules of Order" - the universally accepted Robert's Rules of Order would only apply if the BCTF Rules were "silent on a question." ${ }^{2} 2$ As a senior official noted later, the BC College of Teachers was apparently being regarded merely as "an extension of the Federation." ${ }^{43}$

The New Democratic Party had been in power in British Columbia for 10 years by 2001 , and the education portfolio had been in the hands of nine ministers, so it is hardly surprising that the College of Teachers and its operations had not been a major priority for the education ministry. ${ }^{44}$ After the minor changes to the Teaching Profession Act in 1993 the College had been left very much to its own devices, but the election of the Liberal party to power in 2001 heralded a very different approach to government, as promises of tax cuts, privatization of services, government downsizing, and similar policies sparked a predictable conflict with many groups, in particular the public sector unions.

The BCTF was highly critical of the new government, which in turn had little respect for the teachers' union, suggesting that it was unduly influencing the decisions of the College in favour of its members by not setting clear standards of teacher competence or being responsive to complaints from the public. ${ }^{45}$ In May, 2003, significant amendments were made to the Teaching Profession Act, some directly affecting teachers, and others more concerned with teacher education. The number of elected members of the council was cut from 15 to eight, the right to make bylaws "respecting the training and qualification of teachers" had the word "training" deleted, and the power of the Teacher Education Programs Committee was reduced by the removal of any reference to evaluation from the description of their involvement with the universities' programs. ${ }^{46}$

\section{Members of the Council of The College of Teachers}

\begin{tabular}{|l|r|r|r|}
\hline & $\mathbf{1 9 8 7}$ & May 2003 & December 2003 \\
\hline Elected & 15 & 8 & 12 \\
\hline Appointed & 5 & 12 & 8 \\
\hline
\end{tabular}

(Vote of two-thirds of the Council-14 members - required to amend by-laws)

Naturally, the BCTF was strongly opposed to the changes, claiming that a democratically elected body had been replaced by a group of "political appointees." ${ }^{47} \mathrm{~A}$ month later the members of the BCTF voted to withhold their annual dues to the 
College to protest the changes. ${ }^{48}$ The long-term implications of this action - a potential staffing crisis because technically teachers would not be permitted to teach in public schools if they were not current members of the College-prompted the government to amend the legislation once again, this time making provision for the council to have a majority of 12 members "democratically elected by all members of the college including independent and public school teachers, principals, viceprincipals and superintendents." ${ }^{39}$ The wording used was clearly a reminder to the BCTF that not all members of the College are also members of the union, a message underlined by the new requirement for an oath of office to "ensure that all members of the College council put the public interest first - above all other interests" [emphasis in original]..$^{50}$ Thus, although the BCTF-sponsored elected members would again be in the majority, they still would not have the two-thirds majority needed to change the all-important bylaws, and would have to convince at least two of the other eight members of the council to vote with them. The aims of the legislation were summarized by Christy Clark, Minister of Education and Deputy Premier, in December, 2003:

We had three goals when we introduced Bill 51: First, the college must be independent ... second, there must be clear standards of competence for teachers . . . third, there must be a formal complaint process, just like [sic] there is for doctors, nurses and lawyers. ${ }^{51}$

When the disputes were merely between the College and the faculties of education there was not much outside interest.However, there was growing evidence of public concern on two fronts: first, complaints about teacher conduct and competence did not seem to be taken very seriously, except in the most high-profile and extreme cases which came before the courts, and secondly, the interests of other legitimate stakeholders in the education system, represented on the College Council by appointees from parent groups, independent schools, and school administrators, were being overlooked and overruled to suit the agenda of the teachers' union.

In 2005, the various amendments and alterations to the legislation were consolidated into the new version of the Teaching Profession Act, which also contained some other important provisions and clarifications. ${ }^{52}$ The place of the Oath of Office, which aimed at neutrality, was clarified, the role of the Teacher Education Programs committee was limited to cooperation with teacher education institutions, and teachers were legally required to report severe professional misconduct in regard to students on the part of their colleagues promptly and directly to the Registrar of the College. ${ }^{53}$ This latter clause appeared to be a counter to the BCTF Code of Ethics, which required a teacher to bring any concerns about a colleague's performance to that colleague in private, and only after that could the teacher inform 'appropriate individuals. ${ }^{54}$ The newly constituted College continued to function, albeit with a somewhat lower profile, for the next five years, but it was apparent to many (both inside and outside the College) that all was not well, and that its independence as a professional body was still seriously compromised. 


\section{Died on Saturday}

Matters came to a head in December, 2009 when a Governance Committee Report tabled with the College Council made numerous recommendations "apparently intended to strengthen the ability of the College of Teachers to act, and be seen as acting, independently." 55 The package of reforms never came to a vote, and following this stalemate a majority of the Council decided to take their concerns directly to the Minister of Education. Their call for review was supported by provincial organizations representing school trustees, parents, principals and vice-principals, superintendents, and independent schools, and by several individuals who had previously held positions as Chair or Registrar of the College. ${ }^{56}$ In May, 2010, the Minister of Education appointed a former Deputy Minister, Donald Avison, as a fact finder to determine if the College was fulfilling its mandate under the Teaching Profession Act, and to compare its performance to other similar governing bodies. He submitted his report five months later, in October, 2010.

The validity of Avison's conclusions was reinforced by the concurrence of several present or past Council members and staff who had originally supported the BCTF's position and its attempts to dominate the College, but who had subsequently changed their minds. Norm Nichols, Vice Chair until the 2010 elections, concluded that the BCTF viewed the College "simply as an extension of the Federation. This perception does nothing to serve the interests of the College, the public perception of the College, or its legislated mandate to serve in the public interest." ${ }^{57}$

In this context it is worth noting that neither the Registrar at the time, himself a former President of the BCTF, nor two other former Registrars, "thought that the elected Council members were sufficiently attentive to the need forindependence from the union" - at least some of the senior administrators were clearly concerned with the direction the Council was taking. ${ }^{58}$

In addition to agreeing with many of those he interviewed, both inside and outside the College, that as an organization it was dysfunctional in its present form, Avison cited several instances which seemed to indicate that the College was not acting in the public interest:

- A former elected council member was found in possession of child pornography. His computer was at some point taken into the possession of the BCTF instead of being immediately handed over to the police. No action was taken against the Federation official who had given improper advice about what to do with the computer. ${ }^{59}$

- A teacher convicted years earlier of charges involving sexual assault on students had his teaching certificate reinstated.

- A person sentenced to six years for his role in a narcotics trafficking scheme was found fit to be credentialed as a teacher. 
- A person who had been "permitted to resign" from the Law Society after multiple complaints, including that of forging court documents, was found fit to be granted a teaching credential.60

If the public had understandably not shown much interest in the internal workings and governance of the College of Teachers, these particular examples made headlines, as no doubt they were intended to do.

Avison's conclusions were quite unequivocal:

1. The assessment of the College as dysfunctional was accurate;

2. The BC Teachers Federation had acted overtly to limit the scope of authority exercised by the College;

3. There was not a proper balance between the the "public interest" and the more dominant "interest of members;"

4. The College of Teachers fell well short of the standards set by other selfregulating professions;

5. The Council was more preoccupied with procedural complexity than with protecting the public interest;

6. The Council had lost the confidence of many in the broader educational community. ${ }^{61}$

Faced with this damning report and the public's reaction to it, the BCTF really made no serious attempt to refute either the content or the conclusions. The Federation announced that it was

Deeply distressed by the findings ... the three instances [of improper teacher certification] cited by Avison are shocking on the face of the information provided. It is our expectation that these incidents will be immediately examined by those in the BCCT responsible for upholding the high standards of the profession. $^{62}$

It should perhaps be noted that at the time of the release of the report the BCTF was fully engaged in a bitter dispute with the government over workload, wages, and benefits, an indicator suggesting where its real priorities lay.

Avison's recommendations were equally clear:

Unlike other bodies established to preside over professional regulation, the College of Teachers has never achieved the commitment to common purpose and the focus on professional currency and competence that guides the work of other such bodies. . . . It may be time for the Government of BC to reassert control over the teaching profession by bringing all related functions back within the Ministry of Education. ${ }^{63}$

The death knell had sounded. 


\section{Buried on Sunday}

Cabinet met, consultations were undertaken, decisions were made, new legislation was prepared, and a year later just six words in Bill 12, the new Teachers Act, told the whole story: "The College of Teachers is dissolved." "Avivison's fact-finding report had provided the government with all the evidence it needed to justify this move, and indeed there was little opposition from any of the protagonists.

Teacher certification became the responsibility of a Commissioner and a Director of Certification appointed by Cabinet and reporting to the Minister of Education. Their staff are Ministry employees and all fees are paid to the Ministry.

The British Columbia Teachers Council was established in 2011 to set "standards for the education of applicants for certificates of qualification ... and for the conduct and competence of applicants for certification and certificate holders." ${ }^{65}$ This Council is not merely a reincarnation of the College of Teachers, in spite of superficial similarities. Three members are 'certificate holders' (defined as persons who hold a certificate of qualification or an independent school teaching certificate) nominated by the BCTF, but the Federation must nominate no less than nine certificate holders from whom the Minister of Education will select three. ${ }^{66}$ There are also five other elected certificate holders, and eight persons appointed by the Minister. Seven of the appointees must represent other educational bodies: the Faculties of Education, the Confederation of Parent Advisory Councils, Principals and Vice-Principals, Superintendents, School Trustees, Independent Schools, and the First Nations Education Steering Committee. ${ }^{67}$ These associations must each submit at least three names, from which the Minister will choose one. ${ }^{68}$ One ministerial appointee is a non-voting council member who "must report to the Minister on the activities of the council." ${ }^{69}$ The final word on any decision made by the Council rests with the Minister of Education who "may disallow a rule, standard or decision within 60 days of its submission" - it is quite apparent where the real power is situated. ${ }^{70}$

Disciplinary matters are the responsibility of the Disciplinary and Professional Conduct Board, composed of nine council members appointed by the Minister: four of these are to be from those appointed by the BCTF or elected by teachers, and five from those appointed by the Minister. ${ }^{71}$ Individual disciplinary panels shall consist of three Council members, of whom not more than one is elected by teachers or nominated by the BCTF. ${ }^{72}$ Hearings are to be conducted under the neutral provisions of the Administrative Tribunals Act. ${ }^{73}$

In 1987, the College of Teachers was granted three main areas of responsibility: teacher certification, disciplinary matters, and professional development and cooperation with the Faculties of Education over teacher education. These duties have now effectively been returned to the Ministry of Education, as although the new BC Teachers Council technically has some powers, the Minister of Education has the final say in the selection of members of that Council and over their decisions.

What is quite extraordinary is that there has been no real opposition to this, either from teachers or from the general public. It is hard to imagine a similar reception if, for example, the provincial government had summarily disbanded the College of 
Registered Nurses of British Columbia or the College of Physicians and Surgeons. A 2011 BCTF newsletter described the new legislation in a generally neutral manner: the comments referred only to matters concerning teachers as workers, and made no mention of professionalism: "the bill contains few procedural protections for teachers;" "the creation of a commissioner . . . leaves open the possibility of a process that is inquisitorial to the point of compromising the basic rights of teachers;" "the Federation is concerned about the potential for [discipline hearings] to be 'show trials';" "publication of [consent resolution agreements] . . . would seriously compromise the privacy of teachers who are struggling with health problems and other challenges." It also suggested that as the Act "removed teachers' rights of self-regulation," the Council should be funded by the Ministry, and not by members' annual dues. ${ }^{74}$ A typical reaction was this tortuously guarded comment made by the Dean of Education of Simon Fraser University, who said the new system "eliminates any appearance of unfairness that existed when teachers' union members dominated the college council . . . I think it removes that potential for perception that things could have been unfair." 75

There is perhaps another reason for the BCTF's apparent lack of concern over the demise of the College of Teachers, one which might give some indication that the new Teachers' Council will be able to operate in the way it was intended to. For some time there have been concerns expressed that the BCTF is exerting an undue influence on the decision-making processes of other elected bodies, especially local Boards of Education, and Parent Advisory Councils. ${ }^{76}$ While teachers' salaries are negotiated at the provincial level, there are still numerous other matters concerning such things as staffing policy and working conditions which are dealt with at the local level: voter turn-out at local government and school board elections is notoriously low, and it is not difficult for well-organized political groups to get their own candidates elected. There is, of course, nothing to prevent teachers running for public office (except as school trustees in the district in which they are currently employed), ${ }^{77}$ and as educators their views and opinions are obviously important, but they must be seen to be concerned primarily with the furtherance of public schooling, which as the College of Teachers' débacle clearly demonstrated, is not necessarily always the same as the agenda of the BCTF.

There were no mourners at the funeral.

\section{Autopsy}

There are some questions which were outside the scope of Avison's report, among them concerns about why the College of Teachers was allowed to apparently put the interests of its members ahead of the public interest for so long. There are several possible answers to this: first, there is the matter of ascribed legitimacy whereby "if a law or policy is enacted by a legitimate political authority, those subject to it are afforded good, though not necessarily decisive, reasons to comply with its directives." ${ }^{\text {" }}$ The College was created by the provincial government, and appeared to be no different from other professional bodies which are largely irrelevant to most people: we only 
ever hear of the Law Society or the College of Physicians and Surgeons when some member is subject to disciplinary action and the matter is reported in the press. Secondly, even within self-governing professions contact between members and the professional body is generally limited to the issuance of certificates: elections, policy directives, and changes to by-laws are of little or no interest to the majority. This also appears to apply to union matters as far as teachers in British Columbia are concerned: BCTF officials and leaders at the local and provincial levels are very active and often vociferous, but a recent long and bitter labour dispute raised some doubts concerning the level of support for the union's hard-line stance. The policy of refusing to undertake extra-curricular activities such as sports coaching or drama production outside school hours, even though these activities are officially described as 'voluntary', was unpopular with many teachers. After a year of confrontation only $52 \%$ of BC's public school teachers actually cast a vote on the wage settlement endorsed by the BCTF — hardly an indication of great involvement by the union's members. ${ }^{79}$

There is really little doubt as to the cause of the demise of the British Columbia College of Teachers, but the comparison microscope is an essential instrument for forensic scientists and pathologists. The Ontario College of Teachers was created in 1998 and experienced some similar problems: there was more than one teachers' union involved, and by 2004 there were questions raised as to whether the unions should have the right to run slates of candidates and sponsor election campaigns - unions are prohibited from running candidates at the Ontario College of Nurses. ${ }^{80}$ The question of the protection of the public interest was addressed in legislation in 2006 with the appointment of the Public Interest Committee which was charged with advising the College Council "with respect to the duty of the College to serve and protect the public interest." ${ }^{81}$ The appointed members of the committee were not teachers, although all had been involved in education in some way: a lawyer, a public health care administrator, and an expert in business management and consulting. Ontario was certainly quicker than British Columbia in identifying and addressing this problem.

It is also instructive to look at the record of the General Teaching Council for Scotland (GTC), the professional teachers' body on which the concept of the BC College of Teachers was based. Established in 1965 as an independent professional body to maintain and enhance teaching standards, and to promote and regulate the teaching profession in Scotland, it has been so successful that in April 2012 the GTC was granted complete independence from government, with "enhanced powers and greater flexibility of operation. As a result the GTC for Scotland became the world's first independent, self-regulating professional body for teaching." 82 Among the responsibilities of the GTC are the following:

1. Setting the standards for Initial Teacher Education and Full Registration of Teachers, and for the positions of Chartered Teacher and Head Teacher.

2. Setting standards for and overseeing the probation of newly qualified teachers and for those from outside Scotland. 
3. Registering teachers for Primary, Secondary, or Further Education.

4. Developing and overseeing programs of Continuing Professional Development for practising teachers and for those who seek promotion.

5. Drawing up a Code of Professionalism, a Framework for Professional Competence, and Guidelines for Fitness to Teach. Dealing with questions of Fitness to Teach: responding to complaints, holding hearings, taking disciplinary action where necessary, and publishing the decisions. ${ }^{83}$

This was what the BC College of Teachers was supposed to do, and it failed utterly. Accepting the fact that the initial legislation, brought in as it was without consultation during a period of conflict between the union and the government, was somewhat ill-advised and even naïve, the blame for this failure rests squarely on the attitude of the British Columbia Teachers' Federation, which rejected the professional aspect of the College's mandate in favour of its own agenda, and put the interests of its members and its own ideology ahead of the public interest. ${ }^{84}$

There is, perhaps, another more subtle reason for the failure of this experiment. Nearly 20 years ago the GTC published an account of the historical development of the Council to mark its $25^{\text {th }}$ year of operation, which included this assessment of the reasons for its success:

The nature of the Council's task does not usually lend itself to platform histrionics, nor is it given to achieve its end by noisy public demonstration. . . If the Council has been cautious, it has been so not least in its care not to squander teachers' money on asinine kicking against the traces or braying emptily at its detractors ... It has been by patience rather than petulance, by persuasion rather than by prerogative, that the Council has achieved so much in so short a time. ${ }^{85}$

Behind the Churchillian rhetoric there is evidence of shrewd observation. It is worth contrasting the the General Teaching Council's highly successful approach to that of the BCTF-dominated Council of the British Columbia College of Teachers: their constant and costly recourse to the judicial system, their apparent failure to learn from experience, and their stubborn refusal to adopt anything but confrontational tactics. ${ }^{86}$ The case for teaching as a profession, rather than merely a job, has suffered a severe setbackin British Columbia: it seems highly unlikely that the concept of teacher self-governance will be resurrected in the foreseeable future, but unfortunately nobody seems to care.

\section{Notes}

1 Allan C. Ornstein, "Towards Increased Professionalism for Teachers," Phi Delta Kappan, 63,3. (1981): 196-198.

2 Statutes of British Columbia: Teaching Profession Act, 1987. 
3 Some of the material in the first part of this paper draws on the author's earlier work, especially "Five Years of Teacher Self-Governance: The British Columbia College of Teachers," Journal of Educational Administration and Foundations 7, 2(1992),46-61. British Columbia Teachers' Federation Members Guide to the BCTF, 1985/86 (Vancouver: BCTF, 1985).

5 Barry Sullivan, Commissioner, A Legacy for Learners: The Report of the Royal Commission on Education. (Victoria: Queen's Printer, 1988),147.

6 Although there was no formal acknowledgement, Dr. Ivor Sutherland, Registrar of the General Teaching Council for Scotland, came to Victoria as a consultant, a role he also played ten years later in the establishment of the Ontario College of Teachers. http://professionally speaking.oct.ca/September_1997/riding.htm (accessed 18 August, 2013). He also discussed this with the author at the Annual Conference of the British Educational Management and Administration Society, Bristol, England in September, 1992, where we both presented papers on teacher professionalism.

7 Statutes of British Columbia: Teaching Profession Act, 1987, Sec. 27.

8 "Executive Report," British Columbia Principals' and Vice-Principals' Association, (BCPVPA) Bulletin, (1987), 1.

9 British Columbia Principals' and Vice-Principals' Association, Issues in Education, 6, 1 (November, 1995).

10 British Columbia Teachers' Federation. BCTF Affiliation. http://www.bctf.ca/AboutUs. aspx?id=3014(accessed April 24, 2012).

11 British Columbia Principals' and Vice-Principals' Association, The Claim for Assets http://www.bcpvpa.bc.ca/file://BCPVPA\%202003/reports/claimsett.html.(accessed7 September, 2011).

12 "Teachers Given \$250,000 to Fight B.C. Labour Laws," Victoria Times Colonist, 16 July, 1987, C9.

13 For more on this and related topics see also Thomas Fleming, Worlds Apart: British Columbia's Schools, Politics, and Labour Relations before and after 1972 (Mill Bay, BC: Bendall Books, 2011)

14 Frances Bula, "Rift growing between college and BCTF," Vancouver Sun, 24 October, 1989, B4.

15 British Columbia Teachers' Federation, Members' Guide to the BCTF 1991-92 (Vancouver : British Columbia Teachers' Federation, 1991), 36.

16 British Columbia College of Teachers, Report to the College of Teachers on teacher education. (Vancouver: British Columbia College of Teachers, 1991).

17 Joe Bowman, Report of the visit of the External Review Team of the College of Teachers to the University of Victoria on the 25 $5^{\text {th }}, 26^{\text {th }}$, and $27^{\text {th }}$ of February, 1991. (Submitted to the Professional Development Committee of the College of Teachers by J. Bowman). Xeroxed.

18 British Columbia College of Teachers, 1994 Annual Meeting: British Columbia College of Teachers. Report of the Teacher Education Programs Committee (Vancouver: British Columbia College of Teachers, 1994), 15.

19 Statutes of British Columbia: Teaching Profession Amendment Act, 1993, Sec. 6,8.

20 British Columbia Teachers' Federation, Professional Development http://www.bctf.ca/ professionaldevelopment.aspx(accessed 23 April, 2013). It is also perhaps significant that among the BCTF's "Many Ways to Grow Professionally" the seventh is "Become active in your local association," and "Begin/continue university studies" is ninth. British Columbia Teachers' Federation, Tools for Self-DirectedProfessional Development http://www.bctf.ca/professionaldevelopment.aspx(accessed 23 April 2013)

21 See, for example, College of Registered Nurses of British Columbia, Continuing Competence Program: Professional Development Checklist, 2012. https://www.crnbc.ca/ Downloads/SRP/Tab\%205/Professional\%20Development\%20Checklist (accessed July 
10, 2012), and College of Pharmacists of British Columbia, Professional Development, 2012.http://www.bcpharmacists.org/professional_development/index.php(accessed 10 July, 2012).

22 Statutes of British Columbia: Teaching Profession Act, 1987, Sec. 23; Education Statutes Amendment Act, 1990, Sec. 6.

23 Statutes of British Columbia: Teaching Profession Act, 1987, Sec. 4.

24 For a more detailed account of the legal proceedings see the following: Alastair Glegg, "Who guards the guardians? The British Columbia College of Teachers and Trinity Western University, "International Studies in Educational Administration, 28,2 (2000): 22-35; Alastair Glegg, "Who guards the guardians? A postscript," International Studies in Educational Administration, 30,2. (2002), 27-31;Harro Van Brummelenand Kevin Sawatsky, "Colliding rights in the schools: Trinity Western University v. the British Columbia College of Teachers," Journal of Educational Thought, 136, 3(2002): 201-228, and, giving the College's perspective, Thomas Berger, One Man's Justice, (Vancouver: Douglas \& McIntyre, 2002).

25 Mr. Justice W. H. Davies, Reasons for judgment in the Supreme Court of British Columbia between Trinity Western University and the British Columbia College of Teachers, 11 September, 1997, p. 7. Docket: S000656. Registry: Chilliwack. http://www.courts.gov. bc.ca/scripts. (accessed 5 July, 2004). It should be noted that the wording (if not the intent) of the current TWU Community Covenant has been modified, and students must now agree to abstain from "sexual intimacy that violates the sacredness of marriage between a man and a woman." Trinity Western University, The TWU Community Covenant. http://twu.ca/studenthandbook/university-policies/community-covenantagreement.html. (accessed 9 August 2012).

26 Mr. Justice W. H. Davies, 24.

27 Challenge Response, Newsletter circulated by Trinity Western University, Fort Langley, BC, 1996.

28 Mr. Justice W. H. Davies, 39.

29 Ibid., 42.

30 The Hon Mr. Justice Goldie, Reasons for judgment in the Court of Appeal for British Columbia between Trinity Western University and the British Columbia College of Teachers, 30 December, 1998, 27. Docket: CA023720. Registry: Vancouver. http://www.courts. gov.bc.ca/scripts

31 Ibid., 85.

32 Trinity Western University v. British Columbia College of Teachers (2001). Decision of the Supreme Court of Canada. Neutral citation: 2001SCC31. File No. 27169. May 17, 2001. http://scc.lexum.org/en/2001/2001scc31/2001scc31.html (accessed 2 August 2012).

33 British Columbia College of Teachers. Annual Meeting, 8 Ma8, 2002, 30. http://www. bcteacherregulation.ca/documents/formsandpublications/annualmeetings/annual_mtg rpt_2002.pdf(accessed 22 April 2013)

34 Annual membership fees made up most of the College's revenue, occasionally supplemented by grants from the Provincial government for specific purposes. Ibid.,34.

35 University of British Columbia v. the B. C. College of Teachers, 2001, Sec. 39, 115, 136. http://www.courts.gov.bc.ca/jdb-txt/sc/01/07/2001bcsc0792.htm (accessed 7 August, 2012)

36 Ibid.

37 British Columbia College of Teachers. Revision of Bylaw 5 and Related Policies. (Document sent to Deans of Education for discussion purposes by the Teacher Education Committee, 14 March 2001) 11,12.

38 Ibid., 1,2.

39 Mr. Justice W. H. Davies, 39. 
40 For further discussion on these points, see also Alastair Glegg, "Right-minded teachers: The Influence of the Socio-political Context on the Preparation of Teachers in British Columbia, 1872-2002," Journal of Educational Administration and History, 37,1. (2005), 19-37.

41 British Columbia College of Teachers, Bylaws of the British Columbia College of Teachers, 22 November, 1990. (Vancouver: British Columbia College of Teachers, 1990), Sec. 1. C.01.

42 These changes were among those noted by Tarry Grieve, Chair of the Interim Council of the College, and distributed on December 22, 2003 to various provincial educational organizations, among them the BC Confederation of Parent Advisory Councils, the BC Public Schools Employers' Association, the BC School Trustees Association, the BC Principals' and Vice-Principals' Association, and the Federation of Independent Schools Associations. The document was forwarded to the author by Fred Herfst, Executive Director of FISA, 8 January, 2004.

43 Donald J. Avison, "A College Divided: Report of the Fact Finder on the BC College of Teachers," October, 2010, 17. http://www.bced.gov.bc.ca/pubs/2010_factfinder_ report_bcct(accessed November, 2010).

44 Ministers of Education in British Columbia under the NDP government: 1991, Anita Hagen; 1993, Art Charbonneau; 1996, Paul Ramsey, Moe Sihota, and Joy McPhail; 1997, Paul Ramsey again; 1998, Gordon Wilson; 1999, Penny Priddy and Joy McPhail again.

45 British Columbia Ministry of Education. Letter from the Minister of Education to members of the British Columbia College of Teachers, 10 December 2003.

46 Statutes of British Columbia. Teaching Profession Amendment Act, 2003. British Columbia Bill $51-2003$.

47 British Columbia Teachers' Federation. "Who are the political appointees?" Teacher Newsmagazine, 16, Special Issue, September 2003.

48 J. Rud, "Majority of Teachers Vote to Withhold College Dues", Victoria Times Colonist, 11 November 2003, A4.

49 British Columbia Ministry of Education. Speaking notes for the Minister of Education, "Changes to the Teaching Profession Act", 10 December 2003. www.gov.bc.ca/content/ images_cabinet_college_speakingnotes (accessed 14 December, 2003).

50 British Columbia Ministry of Education, "Government to change College of Teachers." Notice dated 10 December, 2003.

51 Ibid.

52 Statutes of British Columbia. Teaching Profession Act [RSBC 1996] Chapter 449. http:// www.qp.gov.bc.ca/statreg/stat/T/96449_o1.htm\#section5(accessed 14 August 2006).

53 Ibid., Sec. 9.1(1), Sec. 21(4), Sec. 27.1 (1.1)

54 There has been an addendum to Items 2 and 5 of the Code of Ethics to reflect this legislation: "The teacher directs any criticism of the teaching performance and related work of a colleague to that colleague in private, and only then, after informing the colleague in writing of the intent to do so, may direct the criticism, in confidence, to appropriate individuals who are able to offer advice and assistance.* It shall not be considered a breach of the Code of Ethics for a member to follow legal requirements or official protocols in reporting child protection issues." [Italics in original]. British Columbia Teachers' Federation. BCTF Code of Ethics http://bctf.ca/ProfessionalResponsibility. aspx?id=4292(accessed 15 August 2012).

55 Donald J. Avison, "A College Divided: Report of the Fact Finder on the BC College of Teachers," October, 2010, 5. http://www.bced.gov.bc.ca/pubs/2010_factfinder_report_ bcct(accessed and printed November 2010).

56 Ibid., 6.

57 Ibid., 17. 
58 Ibid., 19-20.

59 Ibid., 23

60 Ibid., 30.

61 Ibid., 32.

62 "BCTF Shocked at Avison Report" BCTF School Staff Alert 2012-11\#9,9 December, 2010. http://bctf.ca/publications/SchoolStaffAlert.aspx?id=21835(accessed 13 April 2012).

63 Avison, 34.

64 Statutes of British Columbia. Bill 20 - 2011 Teachers Act, Sec. 87 (1) (a)

65 Teachers Act, Sec. 10 (1)

66 British Columbia Teachers Council Regulations: B.C. Reg. 2/2012. Regulation 2 (1)

67 Ibid.,Regulation 4.

68 Ibid., Regulation 5 (1) (a)

69 Ibid., Regulation 9 (7)

70 Teachers Act, Sec. 14 (2)

71 Ibid., Sec. 26

72 Ibid., Sec. $57(2)(a)$

73 Ibid., Sec. 41 (1)

74 Ellen Ellis \& Gretchen Brown, “Teachers' Act (Bill 12) changes College governance," Teacher Newsmagazine 24, 3 (November/December 2011). http://bctf.ca/publications/ NewsmagArticle.aspx?id=24467(accessed 13 April 2012).

75 Lindsay Kines, "New teachers' disciplinary agency takes away union power at hearings," Victoria Times-Colonist, 6 January 2012, A3.

76 For example, four Victoria school trustees, all of them current or former teachers, announced they would vote against thebalanced budget the district is legally required to submit on the grounds that it "fails to meet the educational needs of students . . . [because] ... years of underfunding by the B.C. Liberal government have led to severe district shortage of educational assistants, counsellors, teacher-librarians, and specialist teachers." Lindsay Kines "School board may split over budget" Victoria Times Colonist, 15 April 2012, A3. This had been one of the BCTF's main platforms in its ongoing dispute with the provincial government.

77 Statutes of British Columbia: School Act(RSBC 1996) Sec. 32-34

78 John Horton "Political legitimacy, justice and consent" Critical Review of International Social and Political Philosophy,15, 2(2012):129-148http://www.tandfonline.com. ezproxy.library.uvic.ca/doi/full/10.1080/13698230.2012.651015 (accessed 3 May 2013)

79 James Keller "B.C. teachers accept new contract, bringing labour peace" Globe and Mail, 30 June 2012. A2

80 Heather Sokolof, Power struggle hits Ontario College of Teachers, Can West News, 5 May 2004, 1 http//:search.proquest.com.ezproxy.library.uvic.ca/ printviewfikle?accountid=14846 (accessed 21 April 2013)

81 Ontario College of Teachers, Public Interest Committee.http://www.oct.ca/about-the/ college/what-we-do-inspring-public-confidence/pic (accessed 21 April, 2013)

82 The General Teaching Council for Scotland. About us. http://www.gtcs.org.uk/aboutgtcs/about-gtcs.aspx(accessed 18 August 2012). Information about the GTC's activities is taken from this source.

83 Ibid.

84 Avison, 32

85 John L. Whiteford "The background of the establishment of the Council and its historical development" The General Teaching Council for Scotland Handbook (5th. Ed.) (Edinburgh: General Teaching Council for Scotland, 1990), 30.

86 See also Fleming, Worlds Apart, 117. 